\title{
The Impact of Corporate Governance Mechanisms on Compliance with IFRS and Financial Reporting Quality
}

\author{
Cheng-Wen Lee ${ }^{1}$ and Yi Tang $\mathrm{Hu}^{2}$
}

\begin{abstract}
The present study examines the impact of corporate governance mechanisms on compliance with IFRS and financial reporting quality, especially focusing on nonaudit service and accountant's tenure. The adoption of IFRS is launched in Taiwan since 2012. The study aims to investigate this issue using a sample of 3997 data gathered from listed companies traded on the Taiwan Stock Exchange and OTC over the period from 2012 up to 2019. The results show the evidence to support that the collective effect of non-audit services/accountant's tenure on audit quality has changed to be more influential. This research findings also open valuable insights to regulators, stock markets, practitioners, and academicians in this issue.
\end{abstract}

JEL classification numbers: D22, G32, M41.

Keywords: IFRS, Non-audit services, Accountant's tenure.

1 Professor, Department of International Business, Chung Yuan Christian University, Taiwan.

2 Ph.D program in Business, College of Business, Chung Yuan Christian University, Taiwan.

Article Info: Received: February 22, 2021. Revised: March 21, 2021.

Published online: March 22, 2021. 


\section{Introduction}

Around the business world, profit is undoubtedly the core of corporate decisionmaking. However, the Enron case outbreak has made the emergence of moral responsibility a core issue for sustainable corporate development (Grayson \& Hodges, 2017). In recent years, Taiwan's corporate financial fraud incidents have emerged one after another, and there is even an increasingly hot trend; e.g. Donglong Hardware, the domestically-made industry's asset hollowing case, Liba (Daily et al., 2009), Boda (Veres \& Boda, 2000), Huangtong (Weng et al., 2009), Xunde (Reiter, 2002), Hongshiying Technology (Yang, Wang, \& Chang, 2020), and Taiwan's Kangyou Pharmaceutical Incident (Lin, 1994).

The hollowing out of funds and fraudulent accounts of biotech companies have again highlighted the seriousness of moral decay. When the scandals of high-level self-gratification and fraud caused capitalism, corporate ethics has become a hot topic, and its importance is no less than profit. A lot of previous studies have pointed out that business ethics no longer hinders companies profit; on the contrary, it can improve the enterprise's efficiency, which is an essential factor for the enterprise's success (Soloman \& Hanson, 1985). The investing public make various decisions based on the financial statements issued by the enterprise, while the auditors of the accounting firm judge the financial statements of the audited enterprises with their independence by the code of ethics and conduct, provide audit reports, and empower users of financial statements to assess financial information. The high degree of trust in financial statements (Warming-Rasmussen \& Windsor, 2003); therefore, auditors shoulder the responsibility of protecting the public investment.

Their judgments must be fair, objective, and independent like judges' judgments (Mautz \& Sharaf, 1961); since it violates ethical principles, the sacrifice will be investors' interests and society's economic well-being. Among many professional fields, auditors' moral attitude should be the worthiest of concern among ethical issues. Professional ethics mainly involves the discussion of ethical issues. Since professionals have professional skills, they must regulate how they use their professions, mostly because professionals have individual behavioral decisions while providing professional services to the public. The general public lacks this professional ability because they have not received relevant training (Bingimlas, 2009). This unique knowledge is usually accompanied by authority and power; most of the available customers trust accountants' professionalism, and they think that the services they provide are beneficial to them. Some professional organizations have set up internal codes of conduct to perform their professional tasks to protect customers' rights and professionals' dignity. This is not only beneficial to customers but professionals themselves. The numerous financial and accounting scandals that have occurred in the past few years have prevented CPAs (Certified Public Accountants) and financial managers at all levels from gaining the trust and recognition of the outside world (Ball, 2009). The outside world usually expects CPAs to have a high standard of professionalism, and at the same time, they must consider the public interest when performing their tasks (Mintz, 1995). 
The professional, ethical behavior of accountants plays a significant role in achieving their accounting duties, providing financial review reports, and maintaining their professional accounting credibility. The author hopes that through the study and application of the professional ethics theory of accountants and the legal responsibility of financial report auditing, the author believes that practitioners of the accounting firm, the accounting education system, and relevant units that formulate accountant ethics will have a more profound and correct understanding (Li, 2019).

There have been many fraud cases involving false financial reports in Taiwan and other foreign countries. In particular, the recent Kangyou case in Taiwan has the most significant impact on accountants' image and reputation (Huang \& Kung, 2010). In the early days, the Enron case abroad had the most significant impact. Institutions, users of financial statements, and scholars are all concerned about whether the provision of non-audit services and the tenure of accountants affect auditing quality, but there is still no conclusion. In the past, domestic literature has separately explored the relationship between non-audit services and the independence of accountants or the tenure of accountants and the freedom of accountants. Huang \& Kung (2010) explore the impact of non-audit services and accountants' term on audit quality. They find that non-audit services are significantly and positively correlated with absolute value and positive adjudication accountability, indicating that primary non-audit services may affect accountants' independence. Besides, as the accountant's tenure increases, total weight and positive adjudication accountability should be accounted for significantly reduced. The adverse impact of non-audit service fees on audit quality will be reduced. Huang \& Kung (2010) further find that clients pay more attention to reputation comparing with short-term accountants and long-term accountants providing nonaudit services simultaneously. Hence, the non-audit service public expense has less impact on audit quality. Frequent rotation of accountants only causes unnecessary cost increases and fails to improve audit quality. Moreover, when accountants' process results in a shorter tenure, once the public fees for non-audit services are higher, low audits may occur (Costa et al., 2019).

This research provides empirical evidence on whether non-audit services and accountants' tenure affect audit quality, but this research still has some limitations. The type and amount of non-audit services will only be disclosed if certain conditions are met. Therefore, if the company purchases a low amount of non-audit public expenses or accounts for a lower proportion of the audit general costs, although it is the purchase of both non-audit services and audit services, it cannot be included. Under the sample of non-audit services, this study cannot assess such samples' impact on audit quality. Secondly, when discussing audit quality, there are many ways to measure including the issuance of audit opinions with doubts about continuing operations, adjudication, and earnings target (Nelson, Elliott, \& Tarpley, 2002). 


\section{Literature Review}

\subsection{Auditing Principles}

The audit method refers to the behavior of the audit subject. The audit method is the procedure used by the auditor to collect audit evidence. In terms of audit methods: inspection, monitoring, observation, inquiry, verification, analysis procedures, and calculations can be used, and sampling audit techniques can all be used. Auditing is to collect and analyze data to assess a company's financial status and then make a conclusion and report on the degree of correlation between the data and generally accepted standards. The audit claims on economic activities and events, and the degree of compliance with the relevant established standards, objectively collect and evaluate relevant evidence systematically, as the basis for verifying the degree of compliance and communicating the audit results to interested parties. The personnel conducting the audit must be independent and possess relevant professional knowledge.

\subsection{Audit Verification Method}

If auditors still use traditional audit techniques and methods in the computerized information system environment, their audit effectiveness and efficiency will be significantly reduced. It will be challenging to achieve their audit tasks and goals satisfactorily. Early computer audit strategies tend to bypass computer audits, focusing on comparing the reasonableness of the relationship between system inputs and outputs instead of directly checking or verifying information system processing (that is, not now verifying the programs or software in the system). When the degree of computerization of the organization's information system is not high, this strategy may achieve the audit purpose but still bear a considerable audit risk. In a highly computerized environment, auditors should no longer limit themselves to bypassing computer audits and actively implement an audit strategy through computer audits. In other words, the scope of information system audit should cover the overall security of the system, program development, program modification, system processing, original data and data files, etc., and use effective technologies and methods to directly verify system input, processing, storage, and output -- the integrity and reliability of the operation process at each stage. As far as the audit's timing is concerned, computer audits can be synchronized audits (such as online real-time processing systems) or post audits (such as batch operating systems) depending on the complexity of the computer environment. When selecting an information system audit strategy, the audit department should consider factors such as the auditor's computer technology and ability, the availability of audit trails and related documents, and related cost-effectiveness (including the limitation of audit time). 


\subsection{Auditing Practice}

In recent years, due to the highly information-based environment, to effectively prevent fraud, accountants need to be able to conduct continuous analysis and detection, but also take into account the risk of false alarms and the large amount of computer data generated by individuals in their daily life or workplace It is believed that general company executives have no ability or time to check the source of the authenticity and integrity of the transaction. According to the definition of American Accounting Institute (AAA), audit (or audit) refers to "obtaining and evaluating the evidence related to the statements of economic actions and events objectively through systematic procedures, to confirm the degree to which these statements meet the established standards, and report the results to the relevant users." In the future, the computer audit method will be widely used as a tool for accountants to audit the financial affairs, which will lead to the audit mode of the company and the accounting industry to reduce the workload to achieve the goal of the management class to implement the financial quality policy actively and fulfill the purpose of supervising the company's operation. This study first collects the literature related to audit risk and then makes a comprehensive discussion after adding immense data literature.

\subsection{Overview of GAAP and IFRS}

Although GAAP (American general accounting principles) is the accounting standard used in the United States, IFRS (International Financial Reporting Standards) is the accounting standard used in more than 110 countries worldwide. Generally accepted accounting principles are regarded as a more "rule-based" accounting system, while IFRS is considered a more "principle-based" system. The Securities and Exchange Commission is also considering a shift to international financial reporting. As detailed in the table above, both GAAP and IFRS aim to provide relevant information to a wide range of users for financial statements. However, while GAAP provides separate objectives for commercial and noncommercial entities, IFRS has only one aim for all types of entities. For revenue presentation, GAAP highlights stable earnings results year after year and provides investors with a view of normalized results. For example, taxes are reported according to the statutory tax rate, not the company's amount. These are designed to help investors understand the company's average capital investment and taxes. In the notes, GAAP requires that the financial statements include a balance sheet, income statement, changes in shareholders' equity, cash flow statement, and notes. It is suggested that the current assets and fixed assets should be separated in the balance sheet, and the deferred tax should be included in the assets and liabilities. Minority interests are included in penalties as a separate item. International financial reporting standards require that financial statements have a balance sheet, income statement, changes in shareholders' equity, cash flow statement, and notes. It is necessary to separate current assets from non-current assets and liabilities. Deferred tax should be shown as a separate item on the balance sheet. Minority interests are 
included in equity as a particular item. According to generally accepted accounting principles, companies must disclose information about accounting choices and expenses in footnotes. Intangible assets: according to generally accepted accounting principles, acquired intangible assets (such as $R \& D$ and advertising expenses) are recognized at fair value, but according to international financial reporting standards, they are only recognized when the assets have future economic benefits, and the reliability is measured.

The United States generally accepted accounting standards define assets as future economic benefits. Still, according to the international financial reporting standards, purchases are the resources of expected economic benefits. According to the United States, fixed assets are generally accepted accounting standards. Fixed assets (such as tangible fixed assets) are calculated using the cost model (i.e., historical value assets minus accumulated depreciation).

The revaluation model is allowed under IFRS based on the fair value valuation date less subsequent accumulated depreciation and impairment losses.

In the framework of IASB, the basic assumptions such as accrual basis under the definition of IFRS by IASB. Compared with the generally accepted accounting principles of the United States, the international financial reporting standards better develop the concept of going concerned. However, international financial reporting standards will still affect them. For example, in global M\&A, there are non-U.S. subsidiaries and non-U.S. stakeholders, such as investors, customers, and manufacturers. In some cases, U.S. companies may be required to provide financial information by international financial reporting standards. For some U.S. companies, the imminent transition from GAAP to IFRSs will also be a challenge.

\subsection{Taiwan's Current Situation Applying the International System}

The FSC has announced that companies should disclose in advance the adoption of IFRS-related matters in their financial reports, requiring the first phase of the consolidated financial report of listed companies, trading companies, and the financial industry (excluding credit unions, credit card companies, insurance brokers and agents) in 2011 to disclose:

1) the critical content and implementation of the adoption of the IFRS plan; and

2) the significant discrepancies that may arise between the current accounting policies and the accounting policies that are not used in the preparation of financial reports by the IFRS. 
In addition, the notes to the consolidated financial statements for each period of 2012 should disclose:

1) the critical content and implementation of the IFRS plan, which should also be told if there are changes to the program;

2) the significant differences that may arise between the current accounting policy and the accounting policy that is not used to prepare financial reports in accordance with IFRS, including the amount of impact that may have on essential items in financial statements after the adoption of IFRS, if the company fails to estimate the amount of the effect;

3) the Company shall state the reasons for the impact;

4) the Company shall state the reasons for the impact;

5) the Company shall state the reasons for the impact;

6) the Company shall state the reasons for the impact;

7) the Company shall state the reasons for the effects;

8) the Company shall state the reasons for the impact;

9) the impact of the Company shall state the result of the impact;

10) the Company shall communicate the impact of the for the first time, and

11) the company adopts the accounting policy chosen by the provisions of IAS in accordance with IAS Bulletin No. 1 (IFRS 1).

IFRS 1 "First Use of IFRS" plays an important role in the enterprise conversion IFRS, enterprises do not adopt IFRS 1 every year, only in the preparation of the "First IFRS Financial Statements" can be applied, so it is a once-in-a-lifetime major choice of the company, related to IFRS accounting amount and future enterprise accounting policies, for the import of IFRS enterprises is of unspeakable importance. The basic principles of IFRS 1 are:

1) identification of the first IFRS financial statements;

2) accounting policies should follow IFRS standards and interpretation orders in force on the "reporting date": when first adopted, all IFRS bulletins that have entered into force on the "reporting date" must be fully retroactively adopted, except for a small number of standards that clearly state in IFRS 1 that the original transitional terms apply and that the transitional provisions of the standards do not apply to first-time adopters; When the Code and Interpretation Order are first adopted, it is necessary to fully retroactively adopt all IFRS bulletins in force on the Reporting Day, and the transitional provisions of the other criteria do not apply to first-time adopters, except for a few of the criteria that clearly state in IFRS 1 that the original transitional clause can be applied.

3) Prepare an open balance sheet for the "conversion date";

4) 5 mandatory exceptions that cannot be retroactive;

5) 17 options for exemptions; and

6) Exposing the Impact of IFRS (Li et al., 2009). In the first identified first IFRS financial report above, "First Use IFRS" is the first time in the notes to the annual financial statements that it clearly and unreservedly states that it follows IFRS, the annual financial statements are the first IFRS Financial 
Statements and the requirements of IFRS 1 "First Adoption IFRS" apply only when the Enterprise prepares the First IFRS Financial Statements.

In the case of listed companies imported in the first phase, the "First IFRS Financial Statements" must be issued on 31 December 2013. The provisions must disclose the comparative financial information for one year, so the IFRS conversion date or opening date falls on the start date of the comparison period, i.e., January 1, 2012, which is the date on which the enterprise issues the first day of financial statements by IFRS 1 .

Compiling IFRS free balance sheets can be a complex and challenging process for companies importing IFRS, especially for group companies with multi-angled operations, complex trading projects, or a long history. To this end, the International Accounting Standards Board considers that specific IFRS provisions may be too tricky to adopt from the outset retroactively or that the cost of execution exceeds the benefits that this information brings to reporting users. Hence, IFRS 1 provides exemption retroactive adjustment items, divided into mandatory and optional categories of exemptions. Five mandatory exemptions: 5 items

1) estimated items that cannot be retroactively adjusted;

2) financial instruments divided;

3) hedge accounting;

4) non-controlling interests; and

5) classification and measurement of financial assets (IFRS 9).

Seventeen selective exemption items:

1) mergers and acquisitions;

2) share-based payments;

3) insurance contracts;

4) recognized costs based on fair value or re-evaluation amounts;

5) leases;

6) employee benefits;

7) Cumulative conversion adjustments;

8) subsidiaries, joint control of individual and affiliated investments;

9) assets and liabilities of subsidiaries, affiliates, and joint ventures;

10) composite financial commodities;

11) designation of recognized financial instruments ;

12) Measure of the fair value of the original recognition of financial assets or liabilities;

13) de-service liabilities in the cost of real estate, plant, and equipment;

14) borrowing costs;

15) service concession agreements

16) assets transferred from clients; and

17) elimination of financial liabilities by equity instruments

These exemptions allow enterprises to choose whether or not to adopt them, depending on the circumstances. 


\subsection{The Relationship between Audit Risk and Audit Quality}

Audit risk refers to the risk (possibility) of the auditor's improper audit opinion; to reduce the difference between the expectations of the reporting user for the accountant's audit report and the current standardized audit report, China's Audit Standards Committee has revised the audit risk model since 2010, issued standard audit bulletin No. 48 to No. 49, and standardized that the inspector should understand the subject and his environment (including internal controls) to identify and assess the risk of significant non-expression, as well as the chance of assessment (Albrecht et al., 2018). Thus, as the basis for the design and implementation of the due check procedures, in 2016 issued audit guidelines bulletin Nos. 57 to 62, significantly adjusted the audit report disclosure content, the introduction of a new type of audit report, and updated key audit matters (KEY Audit Matter, KAM) paragraph to expose the inspection team in the inspection process by the guidelines of bulletin No. 48 identified significant risks and due process. Audit risk is a term commonly used for auditing financial statements. The purpose of the audit of the financial statements is to express an opinion on whether the financial statements have been prepared in accordance with appropriate accounting standards and that the auditee's financial information has been fairly reflected in all material respects (Suwanda, 2015).

The definition of audit quality is the joint opportunity for accountants to identify and report on client accounting systems (DeAngelo, 1981). Therefore, whether accountants can play a super-independent role, and find the major lack of subjects under investigation, is expected by the community. Therefore, the audit quality department is one of the most valued features of accounting firms. The audit quality is positively related to the size of the accounting firm (DeAngelo, 1981). The practice of certified public accountants will operate the accounting firm alone or in partnership with the accounting firm, so its size is tiny. The difference between the audit quality of large and non-large accounting firms and the previous literature focused on the topic; large accounting firms can indeed restrain the audited companies from increasing the surplus of the adjudicative accounting items (DeAngelo, 1981). However, if the same company, replaced by different sizes of accounting firms, by the company's financial figures reflect the quality of the audit, will also vary according to the size of the firm, in recent years, the endless accounting fraud incidents seriously hit the investment public confidence in accountants, statistics show that more and more financial statements are not in line with generally accepted accounting principles are required to be re-edited, the loss of the investment public in the market is also a higher proportion of the financial statements related to the redoing. From the audit checkpoint, this paper discusses whether the accountant's judgment and decision-making in planning, carrying out inspection work, and even producing audit reports are influenced by psychological factors, mainly from the difference of risk preference (Roychowdhury et al., 2019). Accountants with a high degree of risk appetite may risk damage to their reputations and litigation by accounting firms and are easily influenced by client incentives or 
pressures, failing audits; conversely, for accountants with a relatively low-risk appetite, the consideration of reputational maintenance and avoidance of litigation risk may be most essential to ensure the quality of their audits (Cunningham, 2006).

\section{Empirical Analysis Results}

\subsection{Descriptive Statistics}

Referring to Liao \& Hung (2010), our study reviews literature and then selects samples of listed companies traded on the Taiwan Stock Exchange and OTC from 2012 (one year before implementing IFRS) to 2019 (the newest data until now). Simultaneously, the model comparison is made to explore the impact of non-audit services and accountants' tenure on audit quality Impact. To test the hypothesis, this study's model is to test its impact on audit quality through the cross-section regression model of non-audit service and accountant's tenure and the cross-section of the two. Sex should be counted as a substitute variable for audit quality. The impact of non-audit services, accountants' assignment, and other control variables on the corresponding variables is also considered to form the empirical model results.

Table 1 shows that Panel A is the narrative statistics of all samples. At the same time, Panel B and C are the narrative statistics after distinguishing positive and negative sub-samples according to the adjudication. In all the pieces, the average number of non-audited public expenses $(N A S)$ purchases is 0.5715 , which shows that the proportion of significant assets of non-audited general costs from accountants in the sample is specific and more than half of the level. The average (median) of accountant tenure variables (TENU) was 17.51 (17) years, and the maximum tenure was 39 years. The Big Four accounting firms (BIG4) average is 0.8591 , showing that the Big Four accounting firms audit $85.92 \%$ of the samples. $D A=$ adjudication after performance adjustment should be counted; $N A S=$ virtual variable, if the company meets the non-audit public expense disclosure conditions (non-audit public expense accounts for more than one-quarter of the general audit cost or non-audit public expense exceeds 500,000 yuan) Is set to 1 , otherwise it is $0 ; T E N U=$ accountant's tenure, measured in years; SIZE = company size, the book value of total assets at the beginning of the period takes the natural logarithm; BIG4 $=$ virtual variable if the company is checked by the four major domestic firms 1 or 0 otherwise; $C F O=$ cash flow from operating activities divided by total assets; $L E V=$ debt ratio, long-term liabilities divided by total assets; LOSS = dummy variable, one of the company's operating net profit is reported negative. Otherwise, $0 ; L D A=$ the adjudication after performance adjustment for period $t-1$ shall be counted. 
Table 1: Descriptive statistics (all samples from 2012 to 2019)

\begin{tabular}{|c|c|c|c|c|c|}
\hline \multicolumn{6}{|c|}{ Panel A: 2012 vs. 2019 sample $(\mathrm{N}=3,997)$} \\
\hline Variable name & Mean & Median & Minimum & Maximum & Std. Dev. \\
\hline$D A$ & 0.1419 & 0.0000 & -2.1054 & 0.9708 & 0.1234 \\
\hline$N A S$ & 0.5715 & 1.0000 & 0.0000 & 1.0000 & 0.4949 \\
\hline TENU & 17.5100 & 17.0000 & 1.0000 & 39.0000 & 9.6418 \\
\hline SIZE & 14.9669 & 14.8048 & 1.7917 & 22.4442 & 1.8607 \\
\hline BIG4 & 0.8591 & 1.0000 & 0.0000 & 1.0000 & 0.3479 \\
\hline $\mathrm{CFO}$ & 0.2234 & 0.1821 & 0.0000 & 0.9878 & 0.1770 \\
\hline$L E V$ & 0.4492 & 0.4400 & 0.0000 & 38.8150 & 0.6788 \\
\hline LOSS & 0.7760 & 1.0000 & 0.0000 & 1.0000 & 0.4169 \\
\hline$L D A$ & 0.0119 & 0.0000 & -2.1054 & 0.9708 & 0.1234 \\
\hline \multicolumn{6}{|c|}{ Panel B: 2012 samples that should be counted as positive for 2019 adjudication $(\mathrm{N}=2,918)$} \\
\hline Variable name & Mean & Median & Minimum & Maximum & Std. Dev. \\
\hline$D A$ & 0.5370 & 0.0154 & -1.5537 & 0.9708 & 0.5793 \\
\hline$N A S$ & 0.5767 & 1.0000 & 0.0000 & 1.0000 & 0.4228 \\
\hline TENU & 17.7260 & 17.0000 & 1.0000 & 39.0000 & 9.7647 \\
\hline SIZE & 15.0865 & 15.1335 & 1.7917 & 22.4442 & 2.0380 \\
\hline BIG4 & 0.8515 & 1.0000 & 0.0000 & 1.0000 & 0.3545 \\
\hline $\mathrm{CFO}$ & 0.2174 & 0.1740 & 0.0000 & 0.9878 & 0.1789 \\
\hline$L E V$ & 0.4473 & 0.4492 & 0.0000 & 3.1009 & 0.2557 \\
\hline LOSS & 0.7668 & 1.0000 & 0.0000 & 1.0000 & 0.4228 \\
\hline$L D A$ & 0.0310 & 0.0154 & -1.5537 & 0.9708 & 0.1050 \\
\hline \multicolumn{6}{|c|}{ Panel C: Samples that should be counted as negative for adjudication in $2012(\mathbf{N}=1,080)$} \\
\hline Variable name & Mean & Median & Minimum & Maximum & Std. Dev. \\
\hline$D A$ & -0.9261 & -0.6026 & -7.5335 & -0.0005 & 1.0100 \\
\hline$N A S$ & 0.5532 & 1.0000 & 0.0000 & 1.0000 & 0.4973 \\
\hline TENU & 16.9286 & 17.0000 & 1.0000 & 38.0000 & 9.2808 \\
\hline$S I Z E$ & 14.6436 & 14.4734 & 8.0949 & 20.3834 & 1.2052 \\
\hline BIG4 & 0.8767 & 1.0000 & 0.0000 & 1.0000 & 0.3288 \\
\hline $\mathrm{CFO}$ & 0.2398 & 0.2080 & 0.0000 & 0.9379 & 0.1708 \\
\hline$L E V$ & 0.4544 & 0.4148 & 0.0000 & 38.8150 & 1.2373 \\
\hline LOSS & 0.8007 & 1.0000 & 0.0000 & 1.0000 & 0.3996 \\
\hline$L D A$ & -0.0396 & -0.0128 & -2.1054 & 0.5477 & 0.1517 \\
\hline
\end{tabular}

\subsection{Coefficient of Variance}

The correlation coefficients between the variables in this study are grouped in Table 2 , show that the adjudicative count $(D A)$ is positively related to the purchase of nonaudit public expense $(N A S)$ but not significant and significantly negatively associated with the accountant's tenure (TENU). As for the correlation coefficients between the arguments, most of them are below 0.2 . This study also used variance 
inflation factor $(V I F)$ as an additional factor to determine whether there is a standard linearity between variables (Multi-Collinearity) diagnosis. The analysis results found that the VIF values of all arguments in each attribution ranged from 1 to 2 . Therefore, on the whole, the problem of collinearity between variables should not be too serious.

Table 2: Analysis table of correlation coefficients for each variable (all samples from 2012 to 2019)

\begin{tabular}{|c|c|c|c|c|c|c|c|c|c|c|c|c|c|c|c|c|c|c|}
\hline & \multicolumn{2}{|c|}{$|D A|$} & \multicolumn{2}{|c|}{$N A S$} & \multicolumn{2}{|c|}{ TENU } & \multicolumn{2}{|c|}{ SIZE } & \multicolumn{2}{|c|}{ BIG4 } & \multicolumn{2}{|c|}{$\mathrm{CFO}$} & \multicolumn{2}{|c|}{$L E V$} & \multicolumn{2}{|c|}{ LOSS } & \multicolumn{2}{|c|}{$L D A$} \\
\hline$|D A|$ & & & 0.027 & $* * *$ & 0.774 & **** & 0.467 & $* * *$ & -0.001 & & \begin{tabular}{|l|}
-0.004 \\
\end{tabular} & & 0.012 & & -0.018 & $* *$ & 0.037 & $* * *$ \\
\hline NAS & 0.082 & $* * *$ & & & -0.538 & * & 0.062 & & -0.007 & & \begin{tabular}{|l|}
0.006 \\
\end{tabular} & & 0.001 & & 0.006 & & 0.000 & $* * *$ \\
\hline TENU & 0.006 & $* * *$ & -0.001 & $*$ & & & 0.018 & $* * *$ & 0.000 & & \begin{tabular}{|l|}
-0.001 \\
\end{tabular} & $* *$ & -0.001 & & -0.001 & $* *$ & -0.001 & $* * *$ \\
\hline SIZE & 0.130 & $* * *$ & 0.005 & & 0.657 & **** & & & 0.007 & ** & -0.006 & *** & 0.014 & ** & -0.032 & $* * *$ & 0.019 & $\omega$ \\
\hline BIG4 & -0.009 & & -0.014 & & -0.196 & & 0.171 & $* *$ & & & \begin{tabular}{|l|}
0.003 \\
\end{tabular} & & 4 & & -0.001 & & -0.004 & 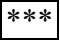 \\
\hline CFO & -0.0 & & 19 & & -1.906 & ** & -0.573 & $* * *$ & 0.015 & & & & & & 0.070 & 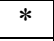 & -0.012 & \\
\hline LEV & 0.019 & & 01 & & -0.214 & & 0.079 & $* *$ & -0.003 & & \begin{tabular}{|l|}
-0.001 \\
\end{tabular} & & & & 0.006 & & -0.002 & F* \\
\hline LOSS & .081 & ** & 0.009 & & -0.760 & \begin{tabular}{|l|l|}
$* *$ \\
\end{tabular} & -0.505 & $* * *$ & 0.000 & & 0.012 & * & 0.018 & & & & 0.003 & $* *$ \\
\hline$L D A$ & 2.381 & $* * *$ & 0.002 & & -10.309 & *** & 4.418 & $* * *$ & -0.004 & & \begin{tabular}{|l|}
-0.032 \\
\end{tabular} & & -0.084 & & 0.054 & & & \\
\hline
\end{tabular}

Note: The bottom left of this table is the Pearson correlation coefficient, and the top right is the Spearman correlation coefficient.

$*, * *$, and $* * *$ in the table represent the significance level of $10 \%, 5 \%$, and $1 \%$, respectively.

\subsection{Single Variable Test}

This study further divided the sample into two parts, which reveal whether the purchase of non-audit public expenses and whether the accountant is a long-term test compares the difference between the average (T-Test) and median (MannWhitney U-Test) between the two groups of samples. The Panel, A system of Table 3 , distinguishes the samples into two sub-samples that reveal the purchase of nonaudit public expenses and the non-audit public expenses that are not revealed. Panel A can be told that in terms of adjudicative counting $(|D A|)$, companies disclose the purchase of non-audit public funds slightly higher than companies that do not disclose the purchase of non-audit public funds but are not statistically significant. In the area of accountant tenure (TENU), the average tenure of accountants of companies that disclose the purchase of non-audit public expenses is significantly lower than that of companies that do not disclose the purchase of non-audit public expenses. As for other variables, there were significant differences in size, BIG4, operating cash flow $(C F O)$, and net operating loss (LOSS). In other words, companies that disclose the purchase of non-audit public expenses have smaller sizes, a higher proportion checked by big four accounting firms (BIG4), a larger operating cash flow (CFO), and a lower rate of net operating loss (LOSS).

Panel B, using the median six-year term of all sample accountants as the demarcation point, divided the sample into two sub-samples checked by long-term accountants (accountants for more than six years), and found that companies checked by long-term accountants, the absolute value of the adjudicative count $(|D A|)$ was significantly lower than that of companies not checked by long-term accountants. Also, the proportion of non-audit public expenses provided by long- 
term accountants at the same time is considerably lower than that of short-term accountants who also offer the purchase of non-audit general costs. As for other variables, the size of the company (SIZE), the big four accounting firms (BIG4), and the net operating loss (LOSS) all made significant differences. In other words, a company with a longer tenure as an accountant has a larger size company (SIZE), a lower rate of an audit by the big four accounting firms $(B I G 4)$, and a higher rate of net operating loss (LOSS).

Table 3: Difference detection of the average and median of the two samples

\begin{tabular}{|c|c|c|c|c|c|c|c|c|}
\hline \multicolumn{9}{|c|}{ Panel A: Whether to expose the difference between non-audit public expenses } \\
\hline \multirow{3}{*}{$\begin{array}{c}\text { Variables } \\
|D A|\end{array}$} & \multicolumn{2}{|c|}{ Yes $(\mathrm{N}=2,384)$} & \multicolumn{2}{|c|}{ No $(\mathrm{N}=1,712)$} & \multicolumn{4}{|c|}{$\begin{array}{c}\text { The difference between the two } \\
\text { samples was determined }\end{array}$} \\
\hline & \multirow{2}{*}{$\begin{array}{l}\text { Mean } \\
0.191 \\
\end{array}$} & \multirow{2}{*}{$\begin{array}{c}\text { Median } \\
0.000\end{array}$} & \multirow{2}{*}{$\begin{array}{c}\text { Mean } \\
0.075 \\
\end{array}$} & \multirow{2}{*}{$\begin{array}{c}\text { Median } \\
0.000\end{array}$} & \multicolumn{2}{|c|}{ T-Test } & \multicolumn{2}{|c|}{ M-W Test } \\
\hline & & & & & 4.463 & $* * *$ & -4.142 & $* * *$ \\
\hline TENU & 17.318 & 16.000 & 17.766 & 18.000 & -0.965 & & -1.810 & $*$ \\
\hline$S I Z E$ & 15.026 & 14.879 & 14.887 & 14.722 & -0.871 & & -2.892 & $* * *$ \\
\hline BIG4 & 0.856 & 1.000 & 0.862 & 1.000 & -0.250 & & -0.344 & \\
\hline $\mathrm{CFO}$ & 0.225 & 0.185 & 0.220 & 0.180 & 0.569 & & -0.728 & \\
\hline$L E V$ & 0.451 & 0.441 & 0.446 & 0.438 & -0.296 & & -0.266 & \\
\hline LOSS & 0.776 & 1.000 & 0.775 & 1.000 & 0.072 & & -0.086 & \\
\hline$L D A$ & 0.015 & 0.003 & 0.007 & 0.000 & 0.592 & & -3.929 & $* * *$ \\
\hline \multicolumn{9}{|c|}{ Panel B: Whether the differences are checked by the long-term accountant } \\
\hline & \multicolumn{2}{|c|}{ Long term $(\mathrm{N}=2,379)$} & \multicolumn{2}{|c|}{ Short term $(\mathrm{N}=1,617)$} & \multicolumn{4}{|c|}{$\begin{array}{c}\text { The difference between the two } \\
\text { samples was determined }\end{array}$} \\
\hline Variables & Mean & Median & Mean & Median & \multicolumn{2}{|c|}{ T-Test } & \multicolumn{2}{|c|}{ M-W Test } \\
\hline$|D A|$ & 0.100 & 0.000 & 0.186 & 0.000 & -2.170 & $* *$ & -2.415 & $* *$ \\
\hline$N A S$ & 0.589 & 1.000 & 0.552 & 1.000 & -1.815 & & -1.606 & \\
\hline$S I Z E$ & 14.811 & 14.740 & 15.135 & 14.898 & 0.130 & & -4.076 & $* * *$ \\
\hline BIG4 & 0.856 & 1.000 & 0.862 & 1.000 & 0.295 & & -0.289 & \\
\hline$C F O$ & 0.230 & 0.192 & 0.216 & 0.172 & -0.038 & & -1.762 & $*$ \\
\hline$L E V$ & 0.457 & 0.438 & 0.439 & 0.443 & -1.341 & & -1.269 & \\
\hline LOSS & 0.789 & 1.000 & 0.761 & 1.000 & -1.246 & & -1.461 & \\
\hline$L D A$ & 0.016 & 0.000 & 0.006 & 0.003 & 6.539 & $* * *$ & -4.812 & $* * *$ \\
\hline
\end{tabular}

a. Variable definitions are the same as Table 1.

b. *, **, and $* * *$ in the table represent the significance level of $10 \%, 5 \%$, and $1 \%$, respectively.

In statistics, the Mann-Whitney U test (also known as Mann-Whitney-Wilcoxon (MWW), Wilcoxon rank-sum test, or Wilcoxon-Mann-Whitney test) is a nonparametric test of the null hypothesis, which is based on randomly selected values From two populations $\mathrm{X}$ and $\mathrm{Y}$, the probability that $\mathrm{X}$ is more significant than $\mathrm{Y}$ is equal to the possibility that $\mathrm{Y}$ is more significant than $\mathrm{X}$. 


\subsection{Multivarision Analysis Results}

Tables 4 shows the regression results of adjudicative should counts with absolute values of contingency numbers. We can see that the coefficient of purchasing nonaudited public expenses $(N A S)$ is significantly positive (up to $1 \%$ ) The significant level) means that when accounting firms also provide customers with major purchases of non-audit public expenses, they are more likely to allow the management authority to manipulate earnings. The accountant tenure variable (TENU) coefficient is negative (up to a significant level of 1\%), which means that the longer the accountant's tenure, the more restrained the management authority from manipulating earnings and the better the audit quality. Also, the coefficient of the purchase of non-audit public expenses and the accountant's tenure payment $(N A S \times T E N U)$ is significantly negative (up to a significant level of $10 \%)$, indicating that as the accountant's tenure increases, the purchase of non-audit public expenses will hurt audit quality. Become smaller.

Also, accountants have different levels of concern about management's manipulation of earnings increase or decrease. They are particularly concerned about the management authority's upward manipulation of earnings (avoid favorable judgment counted as an increase). They are more concerned about management's manipulation of earnings reduction. The looseness is mainly due to accountants suffering from litigation damages, mostly due to its overvalued earnings and net assets (Kapucu \& Van Wart, 2006). Therefore, taking the absolute value of the adjudicative countermeasure to the contingency number may lose some information. This study further divided the sample according to the adjudicative countermeasure into a positive and negative two-sample estimation regression. The results in Table 4 show that in the samples whose adjudication should be counted as positive, the coefficient of $N A S$ is significantly positive (up to a significant level of $1 \%$ ), which is the same as the results of all samples, indicating that the accounting firm also provides customers with substantial purchases When auditing public expenses, the comparison will allow customers to increase the scope of earnings manipulation. This result is the same as the findings of Lim \& Tan (2008).

Therefore, $\mathrm{H} \_1$ in this research is supported. Also, the accountant tenure variable (TENU) is significantly negative (up to a significant level of 5\%). The coefficient of the purchase of non-audit public expenses and accountant tenure payment $(N A S \times T E N U)$ is significantly negative (up to a significant level of $10 \%)$. The same as the results of all samples, it means that the longer the tenure of the accountant, the more important the influence of reputation, the better understanding of the customer's industry characteristics, the more restraining the management authority from manipulating the profit margin, so the purchase of non-audit public funds is detrimental to the audit quality Less affected. This result is consistent with the findings of Lobo \& Zhao (2013). In other words, the longer the accountant's tenure, the better the management's earnings management behavior, and the better the audit quality. $\mathrm{H} \_2$ and $\mathrm{H} \_3$ in this research are supported. However, in the sample whose adjudication should be counted as negative, although the coefficients of NAS, TENU, 
and $N A S \times T E N U$ are in line with expectations, none of them are statistically significant. This result is in line with the phenomenon found in the past literature: accountants' Management authorities have different levels of concern about overestimating and underestimating earnings. Accountants are mainly concerned about avoiding companies overestimating earnings and net assets. They are less concerned about management underestimating earnings and net assets and even optimistic about the outcome ( $\mathrm{Li}$, Chen, \& Cai, 2020). In terms of control variables, first of all, the company size variable (SIZE) showed a significant negative correlation in the sample with positive adjudication, and a significant positive correlation in the sample with negative adjudication, indicating that the company The larger the scale, the less the company will manipulate earnings management. The debt ratio variable $(L E V)$ shows a significant positive correlation in the sample with a positive adjudication and a significant negative correlation in a sample with an unfavorable adjudication, indicating a company with a higher debt ratio; there are more incentives to manipulate surplus to avoid a breach of a debt contract. The net operating loss variable (LOSS) in the two models is significantly negatively correlated, which shows that when the company has already incurred a net loss in the current period, the company will take a big bath and downward earnings management to increase the net profit in the next period. The variable of cash flow from operating activities $(\mathrm{CFO})$, only in the sample whose adjudication should be counted as negative, there is a significant negative correlation.

Furthermore, to increase the robustness of the empirical results of this research, this research still conducts the following sensitivity analysis:

1. As some independent variables are found to have relatively large variability in narrative statistics, lest extreme values affect the empirical results of this research, this research Using Winsorize's approach, the variables were allocated to samples other than $1 \%$ before and after, and their values were set to the same values as $1 \%$ and $99 \%$, and the regression analysis was performed again. The regression results were roughly the same as the original model. Not severely distorted by extreme values.

2. According to Article 22-1 of the "Standards for the Preparation of Financial Statements for Securities Issuers" revised on October 3, 2002, a listed company shall purchase non-audit public expenses from the same accountant to a certain proportion or amount of company Since the fiscal year 2002; it is necessary to disclose information about audited public expenses and nonaudited public expenses in the annual report.

Therefore, not all listed companies need to disclose audited public expenses and non-audited public expenses. In other words, the sample of public expenses is a collection of companies with certain characteristics. , Is a nonrandom sample. If the traditional OLS (Ordinary least squares) estimate may be biased, that is, there is a self-selection bias (Macbeth et al., 2016). To avoid the influence of the selfselection bias in the sample, this article refers to Chatterjee, Pamucar, \& Zavadskas, (2018) and Xue, Zhang, \& Gao (2008) using the two-stage revised estimation method proposed by Heckman (1979) for empirical analysis. The regression results 
are roughly the same as the original model, which shows that these research results are not affected by themselves. Due to the vigorous development of the information electronics industry in recent years, the electronics industry companies accounted for $47.19 \%$ of the sample's observed value in this study. Therefore, to avoid the electronics industry-dominating this research's empirical results, this study adds virtual variables in the electronics industry, re-execute regression analysis. The empirical results found that the electronics industry's coefficient is correct (up to a significant level of 1\%), indicating that investors more favor the electronics industry. Hence, the electronics industry management has the motivation to adjust the surplus upward. After controlling for the influence of the electronics industry, the coefficients of purchasing non-audit public fees $(N A S)$, accountant tenure (TENU), and $N A S$ and $T E N U$ multiplication term $(N A S \times T E N U)$ are still significant and in line with expectations. Therefore, the conclusions of this research are not affected by the industry factor.

Table 4: Effect of purchase of non-audit public expenses and accountant's tenure on the absolute value of the adjudication

\begin{tabular}{|c|c|c|c|c|}
\hline Variables & Direction & Coefficient & \multicolumn{2}{|c|}{ T-Value } \\
\hline$C$ & $?$ & -1.939 & -14.157 & $* * *$ \\
\hline$N A S$ & + & 0.133 & 2.337 & $* * *$ \\
\hline$T E N U$ & - & 0.008 & 3.610 & $* * *$ \\
\hline$N A S \times T E N U$ & - & -0.003 & -1.004 & \\
\hline$S I Z E$ & $?$ & 0.130 & 16.084 & $* * *$ \\
\hline$B I G 4$ & - & -0.009 & -0.243 & \\
\hline$C F O$ & - & -0.097 & -1.267 & \\
\hline$L E V$ & $?$ & 0.019 & 0.974 & \\
\hline$L O S S$ & + & -0.082 & -2.491 & $* *$ \\
\hline$L D A$ & $?$ & 2.379 & 19.870 & $* * *$ \\
\hline Adjusted $R^{2}$ & 0.230 & F-statistic & 133.017 & \\
\hline
\end{tabular}


Table 5: The divided according to the adjudicative count, the effect of purchasing non-audit public expenses and the tenure of the accountant on the adjudication

\begin{tabular}{|c|c|c|c|c|c|c|}
\hline & \multicolumn{3}{|c|}{ DA is a positive sample } & \multicolumn{3}{c|}{ DA is a negative sample } \\
\hline & Direction & Coefficient & T-value & Direction & Coefficient & T-value \\
\hline C & $?$ & -2.1052 & -27.4878 & $?$ & -0.1276 & -0.3078 \\
\hline NAS & + & & & - & 0.1855 & 1.5540 \\
\hline TENU & - & 0.0005 & 0.4408 & + & -0.0010 & -0.2024 \\
\hline NAS $\times$ TENU & - & 0.0026 & 3.0874 & + & -0.0100 & -1.6288 \\
\hline SIZE & $?$ & 0.1732 & 36.3033 & $?$ & -0.0461 & -1.7993 \\
\hline BIG4 & - & 0.0289 & 1.2230 & + & 0.0556 & 0.6506 \\
\hline CFO & - & -0.0292 & -0.6224 & - & 0.1205 & 0.7132 \\
\hline LEV & $?$ & 0.0261 & 0.7903 & $?$ & 0.0129 & 0.5680 \\
\hline LOSS & + & -0.0448 & -2.2260 & - & -0.1093 & -1.5424 \\
\hline LDA & $?$ & -0.0123 & -0.1339 & $?$ & 2.8943 & 14.2227 \\
\hline Adjusted ${ }^{2}$ & & & 0.3930 & & & 0.1729 \\
\hline F-statistic & & & 235.3146 & & & 24.8340 \\
\hline
\end{tabular}

Note: $* * *, * *, *$ indicate $1 \%, 5 \%$ and $10 \%$ significance level. If there is an expected direction, the p-value is a one-tailed test; otherwise, it is a two-tailed test.

\section{Discussion}

In recent years, audit firms have come under increasing pressure after accounting scandals. Regulators around the world are strengthening rules on audits. In 2019, the Financial Reporting Board, the UK's audit regulator, ordered the big four companies -- Deloitte, KPMG, PwC, and EY -- to separate their audit departments from other businesses by 2024. Singapore's regulator recently said all major listed issuers must appoint auditors registered with the Country Accounting and Corporate Regulatory Authority to conduct statutory audits, effectively putting all listed companies under regulatory oversight. Deloitte (Taiwan is one of the world's top 4 accounting firms) to form a large professional audit network of accounting auditrelated institutions around the world, including a total of up to 150,000 professionals, in audit, tax, corporate management consulting, and financial consulting and other four areas for large enterprises, public institutions, and other professional advice and audit services. According to the information provided by the whistleblowers, Deloitte conducted irregularities in the audit process (watering down) and in the execution of the pumping procedures, involving three listed companies, namely China Shipping, Bochy Environmental Protection and Red, Yellow, and Blue Education, which had been known for child abuse. Specific ways of releasing water include implementing essential audit procedures in the audit work and annotating unfinished audit procedures in the under draft. Employees involved in fraud include senior managers, senior auditors, and even partners in the firm. The whistleblower has submitted relevant reporting materials and information to the CSRC, the Securities and Exchange Commission of the United States, the SFC, and other 
regulatory agencies (China News Network Lu Bohua, 2021/02/05) 。

Taiwan and other countries/regions have successively reported many fraud cases with false financial reports, especially the recent "Kangyou Case" (Liberty Times Net, 2020.08) and "Todi Case" (United News Network, 2021.01) in Taiwan, which have the greatest impact on the image and reputation of accountants. In the early days, the Anlong case was affected abroad. Competent authorities of various countries, users of financial statements, and academics are the biggest concerns. They are very concerned about whether the provision of non-audit public funds and the tenure of accountants will affect the audit quality, but they have not yet concluded. In the past, some literature separately discussed the relationship between the purchase of non-audit public expenses and the independence of accountants or the tenure of accountants and the independence of accountants (Daugherty et al., 2012). This study combines the purchase of non-audit public expenses with the accountant's assignment to explore the impact of public non-audit expenditures and the accountant's tenure on audit quality. The empirical results show that the purchase of non-audited general expenses is significant (Lim \& Tan, 2009). It is positively correlated with absolute value and active trial liability, indicating that large-scale purchases of non-audit public expenditure may affect accountants' independence. Also, as the accountant's tenure increases, the absolute value and positive rulings should be significantly reduced. The negative impact of the purchase of non-audit public funds on audit quality will also be reduced. This result supports the findings of previous domestic studies that the purchase of unaudited public expenses will reduce accountants' independence. The quality of financial statements depends not only on the company's preparations but also on the key to determining the quality of financial statements (Harp \& Barnes, 2018). Long-term and other accounting fraud incidents are the best teaching materials for painful experiences. Therefore, this study explores the correlation between the audit quality of the auditing accountants and the reorganization of financial statements. Audit quality uses domestic and foreign documents commonly used to measure audit quality, the importance of non-audit public expenditures, company size, industry expertise, and audit age. Study the correlation between various audit quality institutional variables and restatements of financial statements to conduct a complete analysis of accountants' audit quality (Sarkar, Sarkar, \& Sen, 2008).

The scale of the enterprise is the first four as the measurement standard. Failure to complete the empirical results to support the company's size can reduce the possibility of restatement of financial statements. This study's inference is that the Big Four accounting firms audit $80 \%$ to $90 \%$ of the country's audit market. Therefore, under the oligopoly audit market's unique nature, the Big Four are related to financial statements' restatements. The effect can be seen entirely through empirical results. Also, this may be because in Taiwan, when an accountant issues an audit opinion, the audit opinion is issued in the accountant's name. Therefore, individual certified public accountants have a far greater impact on audit quality than accounting firms. As a result, the scale of Taiwanese accounting firms cannot reach the scale of the United States to maintain audit quality, which has caused some 
irrelevant reasons (Carey \& Simnett, 2006). Non-audit public expenditure is huge, which may prompt accountants and audit clients to reach a compromise, allowing company managers to carry out earnings management and reduce the quality of financial statements, thereby increasing the possibility of financial statements reediting (Bhandari, Golden, \& Thevenot, 2020).

The empirical results show that if the audit firm has a longer inspection period, it can reduce the possibility of restatement of financial statements. The reason is to check all the learning effects and knowledge of long-term affairs, thus reducing financial information re-editing. Also, because Chinese accountants apply for visas in their names, this study's sensitivity analysis redefines the verification period. The empirical results still support this argument. In other words, the verification period is measured by the accountant's last name, first name, or accounting firm. It can be found that the longer the qualifications, the more likely it is to reduce the chance of re-editing the business report (DaSilva \& Trkman, 2014). The empirical results are consistent with the expected direction, indicating that if the audit firm is an industry expert, it can reduce the possibility of restating financial statements.

The reason is that because companies with industry experts have expertise and experience in related industries, they can more effectively detect whether financial statements are fair expression, thereby inhibiting the reorganization of financial statements (Romanus et al., 2008).

Suppose the sample is divided into semi-annual reports and annual reports that need to be "checked," and only the quarterly reports are "checked". In that case, the two sets of samples' empirical results are different. Suppose the non-audit public expenditure is not large, or the inspection company is a professional in the industry, or the inspection experience is longer. In that case, the semi-annual and annual reports can be reduced. As for quarterly reports, only a longer verification year can reduce the possibility of re-editing quarterly reports (Igan \& Mishra, 2011).The empirical results show that if the audit firm has a longer inspection period, it can reduce the possibility of restatement of financial statements. The reason is to check all the learning effects and knowledge of long-term affairs, thus reducing financial information re-editing. Also, because Chinese accountants apply for visas in their names, this study's sensitivity analysis redefines the verification period. The empirical results still support this argument. In other words, the verification period is measured by the accountant's last name, first name, or accounting firm. It can be found that the longer the qualifications, the more likely it is to reduce the chance of re-editing the business report (Cunningham, 2002).

On the other hand, the research limitations of this article mainly include the following three points:

1) Due to the lack of information on non-audit public expenditures; it may be a rough requirement to judge whether non-audit public expenditures are significant under mandatory disclosure (Kang et al., 2017).

2) According to mandatory disclosure regulations, unaudited public expenditures are disclosed in the annual report. This study uses unaudited public expenditures in the annual report. There may be some errors in the year's 
quarterly and semi-annual reports (Darjezi \& Khansalar, 2013).

3) Audit quality variables and other related variables are taken from the "Taiwan Economic News" database (Yang et al., 2020).

Therefore, the correctness of this study's empirical results is limited by the accuracy of the database. This study also found that compared with short-term accountants and long-term accountants who also provide non-audit public expenses, they pay more attention to reputation and better understand client industry characteristics. Besides, the purchase of non-audit public expenses has less impact on audit quality. Frequent rotation of accountants will only lead to unnecessary cost increases and cannot improve audit quality. When accountants' process results in a shorter tenure, auditing may occur once the purchase of non-audit public expenses is high quality. The results of this study, in addition to making up for the lack of empirical evidence on the subject regarding the Taiwan's literature, also shows that the current controversial discussions on the impact of the purchase of non-audit public expenses and the accountant's tenure on audit quality can provide some educational reference value as similar as Bhasin's argument (2016).

This study provides empirical evidence on whether the purchase of non-audit public expenses and the tenure of accountants affect audit quality, but the study still has some limitations (Van \& Vanstraelen, 2008). The type and amount of unaudited public expenditures will only be disclosed if certain conditions are met. Therefore, although the company purchases a smaller amount of unaudited public expenses or a lower proportion of the lower audited public expenses, although the purchase of unaudited public expenses and audited public expenses is the same, it cannot include samples of unaudited public expenditures in purchases. Therefore, this study cannot assess the impact of such samples on audit quality. Secondly, when discussing audit quality, there are many ways to measure it, including issuing audit opinions with doubts about continuing operations, rulings should be made, and whether it has reached the profit target. These can all be studied in the future. If researchers can obtain detailed information about unaudited public expenses in the future, they will study the relevance of unaudited public expenditures. The financial statements are more complete, and it can be checked whether the threshold for mandatory disclosure of non-audited public expenditure is appropriate (Cassar, 2011). The empirical results show that a longer inspection cycle can reduce the occurrence of restatements of financial statements, so it can be provided to the competent authority to evaluate the applicability of the mandatory review policy (Johnson et al., 2019). To ensure that market investors will not cause unnecessary losses due to the quality difference between the semi-annual report, the annual report, and the quarterly report, this study hopes to provide a reference for the competent authority. It must list quarterly reports that actively believe in the inspections theme (Dumontier \& Raffournier, 2002). 


\section{References}

[1] Ball, R. (2009). Market and political/regulatory perspectives on the recent accounting scandals. Journal of Accounting Research, 47(2), pp. 277-323.

[2] Bhandari, A., Golden, J., \& Thevenot, M. (2020). CEO political ideologies and auditor-client contracting. Journal of Accounting and Public Policy, 39(5), p. 106755.

[3] Bhasin, M.L. (2016). Strengthening corporate governance through an audit committee: An empirical study. Wulfenia Journal, 23(2), pp. 2-27.

[4] Bingimlas, K.A. (2009). Barriers to the successful integration of ICT in teaching and learning environments: A review of the literature. Eurasia Journal of Mathematics, Science and Technology Education, 5(3), pp. 235-245.

[5] Cassar, G. (2011). Discussion of the value of financial statement verification in debt financing: Evidence from private US firms. Journal of Accounting Research, 49(2), pp. 507-528.

[6] Chatterjee, K., Pamucar, D., \& Zavadskas, E.K. (2018). Evaluating the performance of suppliers based on using the R'AMATEL-MAIRCA method for green supply chain implementation in electronics industry. Journal of Cleaner Production, 184, pp. 101-129.

[7] Costa, F., Granja, D.A., Fregola, A., Picchi, F., \& Staudacher, P.A. (2019). Understanding relative importance of barriers to improving the customersupplier relationship within construction supply chains using DEMATEL technique. Journal of Management in Engineering, 35(3), p. 04019002.

[8] Cunningham, L.A. (2006). Too big to fail: moral hazard in auditing and the need to restructure the industry before it unravels. Columbia Law Review, pp. 1698-1748.

[9] Daily, G.C., Polasky, S., Goldstein, J., Kareiva, P.M., Mooney, H.A., Pejchar, L., \& Shallenberger, R. (2009). Ecosystem services in decision making: Time to deliver. Frontiers in Ecology and the Environment, 7(1), pp. 21-28.

[10] Darjezi, J.I.Z. \& Khansalar, E. (2013). Frequency of financial reports. International Journal of Business and Management, 8(17), p. 121.

[11] Daugherty, B.E., Dickins, D., Hatfield, R.C., \& Higgs, J.L. (2012). An examination of partner perceptions of partner rotation: Direct and indirect consequences to audit quality. Auditing: A Journal of Practice \& Theory, 31(1), pp .97-114.

[12] DeAngelo, L.E. (1981). Auditor size and audit quality. Journal of Accounting and Economics, 3(3), pp. 183-199.

[13] Dumontier, P., \& Raffournier, B. (2002). Accounting and capital markets: A survey of the European evidence. European Accounting Review, 11(1), pp. 119-151.

[14] Huang, C.L. \& Kung, F.H. (2010). Drivers of environmental disclosure and stakeholder expectation: Evidence from Taiwan. Journal of Business Ethics, 96(3), pp. 435-451. 
[15] https://ec.ltn.com.tw/article/breakingnews/3263371, Kang You involved in false financial reports, Liberty Times Net, 2020/08/01

[16] https://money.udn.com/money/story/5613/4912066,

[17] Kangyou-KY shareholders sued Qinye Zhongxin: No assistance in making false accounts. Economic Daily, 2020/10/15.

[18] https://udn.com/news/story/7238/5184971,

[19] Taodi-KY bursts with false earnings, interviews 5 people, United News Network, 2021/01/31

[20] https://www.chinatimes.com/realtimenews/20210205005425-260409, The world's top Deloitte accounting firm was reported for fraud, China News Network Lu Bohua, 2021/02/05

[21] Igan, D. \& Mishra, P. (2011). Three's Company: Wall Street, Capitol Hill, and K Street. Capitol Hill, and K Street.

[22] Kang, M., Lee, H.Y., Son, M., \& Stein, M. (2017). The association between human resource investment by audit firms and their audit quality. Asia-Pacific Journal of Accounting \& Economics, 24(3-4), pp. 249-271.

[23] Kapucu, N. \& Van Wart, M. (2006). The evolving role of the public sector in managing catastrophic disasters: Lessons learned. Administration \& Society, 38(3), pp. 279-308.

[24] Li, G.Z., Vissers, J.P., Silva, J.C., Golick, D., Gorenstein, M.V., \& Geromanos, S.J. (2009). Database searching and accounting of multiplexed precursor and product ion spectra from the data independent analysis of simple and complex peptide mixtures. Proteomics, 9(6), pp. 1696-1719.

[25] Li, Y. (2019), Corporate operating strategies, and the legal red line: A case study on the criminal liability of financial statement fraud. Master Thesis of Business Management Law, National Taiwan University.

[26] Lim, C.Y., and Tan, H.T. (2008). Non-audit service fees and audit quality: The impact of auditor specialization. Journal of Accounting Research, 46(1), pp. 199-246.

[27] Lin, J. (1994). National innovation in the information age. Sun Yat-Sen Management Review, 12(4), pp. 69-94.

[28] Lobo, G.J. \& Zhao, Y. (2013). Relation between audit effort and financial report misstatements: Evidence from quarterly and annual restatements. The Accounting Review, 88(4), pp. 1385-1412.

[29] Macbeth, F., Noble, S., Evans, J., Ahmed, S., Cohen, D., Hood, K., \& Griffiths, G. (2016). Randomized phase III trial of standard therapy plus low molecular weight heparin in patients with lung cancer: FRAGMATIC trial. Journal of Clinical Oncology, 34(5), pp.488-494.

[30] Mautz, R.K. \& Sharaf, H.A. (1961). The Philosophy of Auditing. American Accounting Association.

[31] Mintz, S.M. (1995). Virtue ethics and accounting education. Issues in Accounting Education, 10(2), pp.247-268. 
[32] Nelson, M.W., Elliott, J.A., \& Tarpley, R.L. (2002). Evidence from auditors about managers' and auditors' earnings management decisions. The Accounting Review, 77(s-1), pp. 175-202.

[33] Roychowdhury, S., Shroff, N., \& Verdi, R.S. (2019). The effects of financial reporting and disclosure on corporate investment: A review. Journal of Accounting and Economics, 68(2-3), p.101246.

[34] Sarkar, J., Sarkar, S., \& Sen, K. (2008). Board of directors and opportunistic earnings management: Evidence from India. Journal of Accounting, Auditing \& Finance, 23(4), pp. 517-551.

[35] Soloman, R.C. \& Hanson, K.R. (1985). It's Good Business. New York: Harper and Row.

[36] Suwanda, D. (2015). Factors affecting quality of local government financial statements to get unqualified opinion (WTP) of audit board of the Republic of Indonesia (BPK). Research Journal of Finance and Accounting, 6(4), pp. 139157.

[37] Veres, A., \& Boda, M. (2000). The chaotic nature of TCP congestion control. In Proceedings IEEE INFOCOM 2000. Conference on Computer Communications. Nineteenth Annual Joint Conference of the IEEE Computer and Communications Societies (Cat. No. 00CH37064) (Vol. 3, pp. 1715-1723).

[38] Van Tendeloo, B. \& Vanstraelen, A. (2008). Earnings management and audit quality in Europe: Evidence from the private client segment market. European Accounting Review, 17(3), pp. 447-469.

[39] Waring, A. (2016). Corporate Risk and Governance: An End to Mismanagement, Tunnel Vision and Quackery. Routledge.

[40] Yang, L.W., Wang, J.L., \& Chang, J.H. (2020). The relation between abnormal accruals and key audit matter: Evidence from Taiwan. 2020 The 6th International Conference on Industrial and Business Engineering, pp. 153-156. 